\title{
STRUCTURAL ANALYSIS OF SPRAY-DRIED COCONUT SHELL LIQUID SMOKE POWDER
}

\author{
[Analisis Struktural Bubuk Asap Cair Batok Kelapa Hasil Pengeringan Semprot] \\ Satrijo Saloko ${ }^{1)^{*}}$, Purnama Darmadji2), Bambang Setiaji ${ }^{3)}$ and Yudi Pranoto ${ }^{2)}$ \\ 1) Faculty of Food Technology and Agroindustry, Mataram University, Mataram \\ 2) Faculty of Agricultural Technology, Gadjah Mada University, Yogyakarta \\ 3) Faculty of Mathematics and Natural Sciences, Gadjah Mada University, Yogyakarta
}

Submitted November 07 2012 / Accepted December $07^{\text {th }} 2012$

\begin{abstract}
The research was aimed at determining spray drying conditions during the production of smoke particulate powder and its consequences on the physical properties of the product. The experiment was carried out using a complete randomized factorial design. Samples were three solution of chitosan (CS)-maltodextrin (MD) based nanoparticles i.e. CS $(0.5 \% \mathrm{w} / \mathrm{v})$ and $\mathrm{MD}(9.5 \% \mathrm{w} / \mathrm{v})$ in acetic acid $(1.0 \% \mathrm{v} / \mathrm{v})$ without liquid smoke (F1), only MD (10\% w/v) in liquid smoke (F2) and a mixture of CS (1.5\% w/v) and MD (8.5\% w/v) in liquid smoke (F5). Each sample solution was prepared at $10 \%$ solid contents with addition of $1.0 \%$ sodium tripolyphosphate. The experimental factors were inlet air temperatures $(\mathrm{T})$ of $130^{\circ} \mathrm{C}$ (T1) and $150^{\circ} \mathrm{C}(\mathrm{T} 2)$ and feed flow rate $(\mathrm{L})$ of $2.4 \mathrm{~mL} /$ minute (L1) and $5.1 \mathrm{~mL} /$ minute (L2). The parameters evaluated included bulk density, yield, moisture content, water activity, morphology and particle size. Results showed that the average particle sizes decreased when the inlet air temperature increased. The bulk density, moisture content and water activity of powders tended to decrease with the increase of inlet air temperature. In contrast, the powder yield increased with increasing of inlet air temperature. Furthermore, characteristics of the powder particulates were spherical with smooth surfaces for all treatments but when the inlet air temperatures was high the particles has deeper surfacial grooving and shriveled, especially for sample F1.
\end{abstract}

Keywords: chitosan, coconut shell liquid smoke powder, maltodextrin, nanoparticle, spray drying

\section{ABSTRAK}

Penelitian ini bertujuan untuk menentukan kondisi pengeringan semprot selama produksi partikel bubuk asap cair termasuk sifat-sifat fisiknya. Percobaan dilakukan dengan menggunakan rancangan acak lengkap faktorial. Sampel terdiri dari tiga larutan berbasis nanopartikel kitosan (CS)maltodekstrin (MD) yaitu pertama CS (0,5\% b/v) dan MD (9,5\% b/v) dalam asam asetat (1,0\% v/v) tanpa asap cair (F1), kedua hanya MD (10\% $\mathrm{b} / \mathrm{v})$ dalam asap cair (F2), dan ketiga campuran CS $(1,5 \% \mathrm{~b} / \mathrm{v})$ dan $M D(8,5 \% \mathrm{~b} / \mathrm{v})$ dalam asap cair (F5). Setiap larutan sampel dengan total padatan $10 \%$ ditambahkan natrium tripolifosfat $1,0 \%$. Faktor penelitian adalah suhu udara masuk $(T)$ terdiri dari 2 tingkat $\left(T 1=130^{\circ} \mathrm{C}\right.$ dan $T 2=$ $150^{\circ} \mathrm{C}$ ) dan kecepatan aliran umpan $(L)$ terdiri dari 2 tingkat ( $L 1=2,4 \mathrm{~mL} /$ menit dan $L 2=5,1 \mathrm{~mL} /$ menit ). Parameter penelitian meliputi bulk density, rendemen, kadar air, aktivitas air, morfologi dan ukuran partikel. Hasil penelitian menunjukkan bahwa ukuran rata-rata partikel menurun ketika suhu udara masuk meningkat. Bulk density, kadar air dan aktivitas air dari bubuk cenderung menurun dengan meningkatnya temperatur udara masuk. Sebaliknya, hasil bubuk meningkat dengan meningkatnya temperatur udara masuk. Selain itu, karakteristik partikel bubuk berbentuk bulat dengan permukaan halus untuk semua perlakuan, tetapi ketika suhu udara masuk semakin tinggi maka permukaan bubuk lekuk dan keriput terutama untuk sampel F1.

Kata kunci: kitosan, bubuk asap cair tempurung kelapa, maltodekstrin, partikelnano, pengeringan semprot

\section{INTRODUCTION}

Production of high-tech materials using nanoparticles is of great scientific interest in order to yield products with superior characteristics. The well established method for it is dispersing nanomaterials in a suspension which successively transformed into a dry form. Spray drying technique produces micron-sized

Paper was Presented at International Conference on "Future of Food Factors", October 3-4, 2012, Jakarta, Indonesia.

${ }^{*}$ Corresponding Author:

Email : satrijo_s@yahoo.com particles from suspensions of nanoparticles and other components having dimensions in the nanometer range. Hence, the spray drying technology may establish a link between the nanomaterial synthesis and the traditional processes which can produce the actual end products using micronsized materials. (Lindeløv and Wahlberg, 2008).

Spray drying is a process of transformation from an emulsion, suspension or dispersion system to a dry state product through atomization and dispersion in a hot gas (Oliveira et al., 2010). Operationally, it is a one-step processing where a liquid feed is altered into powder which concomitantly minimising handling while reducing the bulk weight and size of 
the particles and preserving the product by reducing the water activity required for bacterial degradation (Fang et al., 2005). It has also been used to produce micro-encapsulated materials by a particular carrier used in the feed slurry and selective diffusion. The common carriers include carbohydrates, gums and cellulose esters and ethers. Moreover, mixed carriers are also used as efficient and stable agents in particular feed materials (Drusch et al., 2007). In this process, unstable ingredients are mixed or homogenized in a solution containing materials which envelope targeted components so that it forms a stable suspension. Such solution is called wall materials. The suspension is then fed into a spray dryer where it is converted into dried powder.

The applications of microencapsulation can be found in various food industries; the important examples are coating materials of colorants, flavors, vitamins, and other unstable food ingredients in order to prolong the shelf life (Bansode et al., 2010). In addition, microencapsulation can transform liquids into free-flowing powders to ease handling. Typically, the effective wall materials for spray drying comply with the following properties: good emulsification, film forming, high solubility, low viscosity at high concentrations (Reineccius, 1988) yet biocompatible with living organism cell membranes and degradable as well as cheap.

Micro or nanoencapsulation including micro- or nanospheres or encapsulation is mostly applied in pharmaceutical industry aiming at manipulating pharmacokinetics of a drug release, promote stability and reduce toxicity (Tewa-Tagne et al., 2007). The micro or nanospherical particulates have matrix architectures in which the bioactive compound can be adsorbed at the outer surface or interior pores of the particles yet the bioactive compound is enveloped or encapsulated by polymeric coat inside the particles.

Various natural polymers can be used in manufacturing nanoparticles. In the present study, chitosan (CS) and maltodextrin (MD) is chosen as the polycationic and anionic compounds. CS is a derivative of chitin, a biopolymer found in the shells of crustaceans, cell wall of fungi and other microbia (Pranoto et al., 2005; Anal, 2010). It has high affinity to crosslink with the counterpart polyanions, biocompatibility, biodegradability, antibacterial properties, mucoadhesivity. Moreover, it is nontoxic with a low immunogenicity (Darmadji and Izumimoto, 1994; Anal et al., 2006) and has ability to act as an adsorption improver (Vila et al., 2002). On the other hand, MD is the most commonly used materials for encapsulation of bioactive materials. $\mathrm{MD}$ is water-soluble and capable of protecting ingredient from oxidation. Several studies have explored MD potentials in preserving vitamin $C$ in fruit juice and stability of acerola powder (Dib et al., 2003; Righetto and Netto, 2005).

Among the main factors, feeding-liquid temperature, feed rate, inlet air temperature, flow rate and outlet air temperature (Patel et al., 2009) is important in process optimization. Increased feed temperature should be compensated with reduced viscosity and droplet size. However, high temperatures may cause volatilization or degradation of heat-sensitive ingredients. Controlled feed rate is also important to ensure each droplet adequately dried before it comes in contact with the surface of the drying chamber (Loksuwan, 2007). The lower inlet air temperature, the lower evaporation rate causes the formation of microcapsules which have high density membranes, high water contents, and poor fluidity by which the particles agglomerate easily (Patel et al., 2009). Meanwhile, outlet air temperature will depend on the established specification of drying characteristics. The ideal outlet air temperature for the microencapsulation of food ingredients such as flavors has been reported to be $50-80^{\circ} \mathrm{C}$ (Sebastien, 2004).

Coconut shell liquid smoke has been reported to contain bioactive compounds such as phenols, carbonyls and organic acids. Therefore, the coconut shell liquid smoke is potential in increasing shelf life of proteinaceous food products (Darmadji et al., 2009; Zuraida et al., 2011). The bioactive compounds of liquid smoke needs to be protected against deterioration during the process by mean of encapsulation. However, there is no study reporting the encapsulation of liquid smoke components. In addition, a little is known on combination CS-MD as encapsulates in different concentration into liquid smoke solution.

The objectives of this study were to produce spray-dried coconut shell liquid smoke and to determine the effects of different spray drying temperatures and suspension-feed flow rates on the structure and physical properties of the particulate powders.

\section{MATERIALS AND METHODS}

\section{Materials}

Raw coconut shell liquid smoke used in this study was obtained from Tropica Nucifera Industry, Yogyakarta, Indonesia. This material was purified using redistilation method in the laboratory. Chitosan (CS) was purchased from Biotech Surindo, Indonesia (deacetylation degree $91.5 \%$, moisture $10.43 \%$, ash 0.71\%). Maltodextrin (MD) with Dextrose Equivalent (DE) 10.8\% was from Grain Processing Corp. (lowa, USA), Sodium tripolyphosphate (TPP) and glacial acetic acid (HOAC) were supplied by Sigma Chemicals Ltd. (Munich, Germany). The other chemicals used for analysis were of analytical grade.

\section{Sample preparation}

CS $(0.5 \% \mathrm{w} / \mathrm{v})$ and $\mathrm{MD}(9.5 \% \mathrm{w} / \mathrm{v})$ were dispersed in an aqueous solution of glacial acetic acid $(1.0 \% \mathrm{v} / \mathrm{v})$ as $\mathrm{F} 1$ sample code. CS-MD mixed nanoparticles were prepared with a slight modification of previously described methodology (Grenha et al., 2010), based on the polyelectrolyte complexation of CS with MD and additional ionic gelation of chitosan with TPP anions. Briefly, CS and MD were dissolved in coconut shell liquid smoke based on the various ratios CS : MD (0\%: 10\%) as F2 sample code and (1.5\%: $8.5 \%$ ) as F5 sample code. Sodium tripolyphosphate $(1.0 \mathrm{mg} / \mathrm{mL})$ was added in these mixtures then agitated using a magnetic stirrer at $200 \mathrm{rpm}$ for 30 minute at room temperature. Nanoparticles were isolated by centrifugation (Centrifuge Damon/IEC Division, Connecticut, USA) at 3,000 rpm in a $50 \mathrm{~mL}$ conical tube for 30 minute at room temperature. The supernatant was discarded and nanoparticles were vacuum filtered (Gast, USA) using Whatman \# 2. The solution of 
nanoparticles was heated at $50^{\circ} \mathrm{C}$ into waterbath for 15 minute and was homogenized using a rotor-stator homogenizer (Ultraturrax T50 Basic IKA Werke, Germany) at $5.200 \mathrm{rpm}$ for 2.5 minute.

\section{Drying conditions}

The sampel solution was fed into a Büchi B-290 minute spray dryer (Flawil, Switzerland) for drying. The operating conditions were as follows; aspirator rate 50\%; drying inlet air temperature 130 and $150^{\circ} \mathrm{C}\left( \pm 2^{\circ} \mathrm{C}\right)$, while the outlet air temperature varied between 57 and $82^{\circ} \mathrm{C}$; feed flow rate was set at 2.4 and $5.1 \mathrm{~mL} /$ minute; atomization air rotameter $30 \mathrm{~mm}$ (to the bottom of the gauge ball) and the nozzle cleaner set to 4 . The system was kept running without heating after the completion of the experiment until the inlet air temperature fell below $70^{\circ} \mathrm{C}$. Spray-dried powders were collected, kept in amber bottles and stored under desiccated conditions at room temperature prior to powder characterization.

\section{Bulk density}

Bulk density of powder was measured by weighing $5.0 \pm 0.1$ $\mathrm{g}$ of a sample into a $10 \mathrm{~mL}$ graduated cylinder, rapped gently the cylinder for 3 times. The volume of the powder was recorded and the bulk density was calculated as following relationship.

$$
\text { Bulk density }(\mathrm{g} / \mathrm{mL})=\frac{\text { Weight of powder }}{\text { Volume of powder }}
$$

\section{Production yield}

The percentage of production yield ( $\% \mathrm{w} / \mathrm{w})$ was calculated from the weight of dried microspheres (W1) recovered from each of 3 batches and the sum of the initial dry weight of starting materials (W2) as the following equation:

$$
\text { Yield }=\frac{W 1}{W 2} \times 100 \%
$$

\section{Determination of moisture and water activity}

The moisture content of the samples was measured by hot air oven at $105^{\circ} \mathrm{C}$ for $16 \mathrm{~h}$. The water activity of the samples was measured using Decagon Pawkit water activity meter (EminTech, Sweden).

\section{Scanning electron microscopy}

Scanning electron microscope (SEM FEI type Inspect S50, Oregon, USA) was used to study the surface properties of the spray-dried particulate powders. The particulates were attached to SEM stubs diameter of $10 \mathrm{~mm}$ using a two-sided adhesive tape. The samples were then sputter coated with gold and examined at 10.000 magnifications. An acceleration potential of $20 \mathrm{kV}$ was used during micrograph.

\section{Particle size measurement}

The prepared microspheres suspended in distilated water were sized by using a laser particle size distribution analyzer
(Malvern Zetasizer Nanoseries Nano ZS Ver 6.20, Malvern Instruments Ltd, Malvern, UK). The size distribution was determined by the span value. Triplicate measurement was conducted.

\section{Statistical analysis}

The differences between the mean values of multiple groups were analyzed by one-way analysis of variance (ANOVA) with Tukey Methods range tests. ANOVA data with a $P<0.05$ was classified as statistically significant. MINITABS 16.0 software, Origin 75 and Microsoft Excel 2007 program were used. Mean values from the experiments were obtained from triplicates.

\section{RESULTS AND DISCUSSION}

Visually, the coconut shell spray-dried nanoparticles were white powder especially from sample chitosan and maltodextrin in acetic acid solution $1.0 \%$ (F1), while nanoparticle with combined chitosan and malrodextrin in liquid smoke (F5) were yellowish.
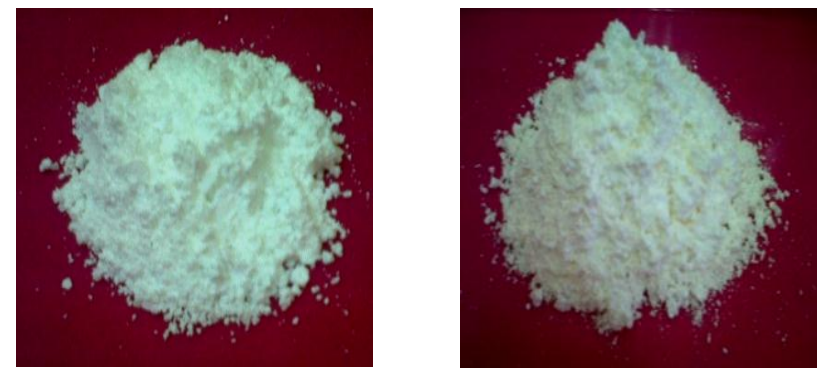

a

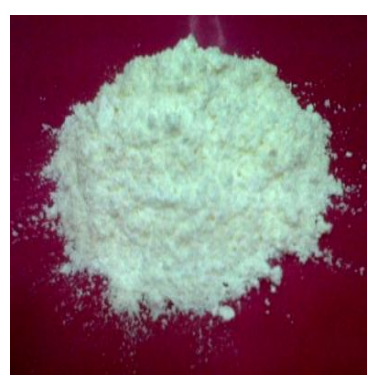

b

C

Figure 1. Spray-dried nanoparticle powders obtained from (a) chitosan $(0.5 \% \mathrm{w} / \mathrm{v})+$ maltodextrin $(9.5 \% \mathrm{w} / \mathrm{v})$ in acetic acid, (b) only maltodextrin $(10 \% \mathrm{w} / \mathrm{v})$ in liquid smoke, and (c) chitosan $(1.5 \% \mathrm{w} / \mathrm{v})+$ maltodextrin $(8.5 \% \mathrm{w} / \mathrm{v})$ in liquid smoke

This was due to an ionic interaction between $-\mathrm{NH}_{3}{ }^{+}$group of chitosan and carbonyls groups of liquid smoke (data not shown). Carbonyls generally contribute to the color of the product once reacted with amino groups. Darmadji et al. (2009) mentioned that bioactive compounds in liquid smoke gave not only preservative and antioxidative effect but also color, flavor and taste to the product.

\section{Moisture content and yield}

Inlet air temperature is an important parameter for spray drying processes and can affect the final powder properties. 
Table 1 shows all affecting factors in spray drying. It can be observed that the inlet air temperature is the main factor affecting powder properties. It was also found that at $150^{\circ} \mathrm{C}$ and high feed-flow rates, water were incompletely evaporated resulting powders with low bulk density and high water content.

The final moisture contents of powders fell into a range of 6.66 to $12.62 \%$. The product yield increased as the inlet air temperature increased from 130 to $150^{\circ} \mathrm{C}$. At $130^{\circ} \mathrm{C}$, deposition of particles adhering on the cyclone wall was observed, which might be due to insufficiently dried droplet/particle within the drying chamber. Consequently, it led to a lower product yield. At inlet air temperatures of $150^{\circ} \mathrm{C}$, the higher moisture removal and product yield was observed. In this systems, the moisture content of the particles was less ca $9.65 \%$ and ca $56.38 \%$ of recovery in the collection vessel and cyclon. In terms of industrial scale up, higher inlet air temperatures could be selected, due to the better water moisture removal and higher product recovery.

\section{Bulk density}

The bulk density of powder is affected by chemical composition, particle size and moisture content as well as by processing and storage conditions (Hong and Choi, 2007). Bulk density values correlated to the particle size as founded that powders derived from CS and MD in liquid smoke had smaller sizes (F5), while that from CS in acetic acid (F1) had the biggest size and hence CS can be contained most tightly and represented the highest bulk density value (Table 1). Reineccius (2004) found that spherical particles had the highest bulk density, the best packing properties and flowing ability. Moreover, according to Fuchs et al. (2006) spherical particulates powders can be compacted better. There is also an advantage of the high bulk density powders, i.e reduction of oxygen permeability, so the shelf life of product can be extended due to inhibition of oxidation. Therefore, the smallest bulk density powders obtained from CS can elicit the suitable characteristic of wall material.

\section{Water activity $\left(\mathrm{a}_{\mathrm{w}}\right)$}

The $a_{w}$ values resulted from CS and MD were in the range of $0.28-0.44$. At the higher total solid contents, the drying rates were higher resulting in a lower $a_{w}$ of the encapsulated powder. Newton (2007) suggests that appropriate $a_{w}$ are between 0.2 and 0.3 because many chemical reactions such as oxidation, and chlorophyll degradation can occur slowly, and no microbial proliferation in such conditions. Moreover, the $a_{w}$ below 0.30 ensures product stability (Drusch and Schwarz, 2006).

\section{SEM of spray-dried powders}

The sample powders were observed for granular surface properties using SEM (Figure 2).

Results clearly showed significant differences in size and shape. Nanocapsules from CS in acetic acid (F1) showed shrinkage and dimpled, while nanocapsules from liquid smoke without CS (F2) showed rounded shape, smooth surface with no obvious dents, and CS in liquid smoke powder showed spherical shape with extensive dented surface. Formation of dented surfaces of spray-dried particles was attributed to the shrinkage of the particles during the drying process (Chin et al., 2010). The extensive dented surfaces of chitosan in acetic acid solution (F1) was probably attributed to maltodexrtin granule disrupted resulted in more susceptible to shrinkage during the drying stages. Patel et al. (2009) suggests that the spherical spray dried particles had high surface/volume ratios showing appropriate characters of spray dried product. Reineccius (2004) recommends that spherical particles can retain the highest amount of flavoring agents. Based on this present result, it is considered that in a mixture of chitosan and maltodextrin were the proper wall materials for coconut shell liquid smoke powders.

Table 1. Characteristics of produced powders

\begin{tabular}{|c|c|c|c|c|c|c|}
\hline Sample & $\begin{array}{l}\text { Inlet Air Temperature } \\
\left({ }^{\circ} \mathrm{C}\right)\end{array}$ & $\begin{array}{l}\text { Feed Flow Rate } \\
\text { (mL/minute) }\end{array}$ & $\begin{array}{l}\text { Bulk Density } \\
(\mathrm{g} / \mathrm{mL})\end{array}$ & $\begin{array}{c}\text { Yield*) }^{*} \\
(\%)\end{array}$ & $\begin{array}{l}\text { Water } \\
\text { Activity }\end{array}$ & $\begin{array}{c}\text { Moisture } \\
(\% \mathrm{db})\end{array}$ \\
\hline F1 & 130 & 2.4 & $0.42 \pm 0.01$ a & $53.83 \pm 0.16^{d}$ & $0.31 \pm 0.01 \mathrm{de}$ & $7.21 \pm 0.46 \mathrm{gh}$ \\
\hline F1 & 130 & 5.1 & $0.36 \pm 0.02 a b c$ & $62.49 \pm 0.50 \mathrm{~b}$ & $0.44 \pm 0.01 \mathrm{e}$ & $8.74 \pm 0.03^{h}$ \\
\hline F1 & 150 & 2.4 & $0.40 \pm 0.01 \mathrm{~cd}$ & $72.53 \pm 1.05$ & $0.28 \pm 0.01 a$ & $6.66 \pm 0.08^{f}$ \\
\hline F1 & 150 & 5.1 & $0.35 \pm 0.01 \mathrm{~d}$ & $73.02 \pm 0.25$ a & $0.41 \pm 0.01 \mathrm{~b}$ & $7.65 \pm 0.05 \mathrm{~g}$ \\
\hline F2 & 130 & 2.4 & $0.42 \pm 0.01 \mathrm{a}$ & $52.63 \pm 0.38 d$ & $0.35 \pm 0.01 \mathrm{c}$ & $11.24 \pm 0.03^{b}$ \\
\hline $\mathrm{F} 2$ & 130 & 5.1 & $0.42 \pm 0.01 \mathrm{bcd}$ & $38.22 \pm 0.28 c$ & $0.42 \pm 0.01$ de & $10.18 \pm 0.20 \mathrm{e}$ \\
\hline F2 & 150 & 2.4 & $0.40 \pm 0.01 \mathrm{a}$ & $57.25 \pm 0.27$ h & $0.31 \pm 0.01 a b$ & $9.87 \pm 0.31$ de \\
\hline F2 & 150 & 5.1 & $0.37 \pm 0.01 a b c$ & $42.45 \pm 1.00 \mathrm{~g}$ & $0.42 \pm 0.02 a b$ & $11.22 \pm 0.07 b c$ \\
\hline F5 & 130 & 2.4 & $0.42 \pm 0.03 a b$ & $48.32 \pm 0.22 f$ & $0.36 \pm 0.01 \mathrm{c}$ & $12.62 \pm 0.22$ \\
\hline F5 & 130 & 5.1 & $0.42 \pm 0.01 \mathrm{bcd}$ & $43.78 \pm 0.44 \mathrm{e}$ & $0.43 \pm 0.01 \mathrm{~d}$ & $10.55 \pm 0.34$ \\
\hline F5 & 150 & 2.4 & $0.39 \pm 0.04 a b$ & $50.42 \pm 0.31 \mathrm{~g}$ & $0.32 \pm 0.01 a b$ & $11.87 \pm 0.27 \mathrm{~cd}$ \\
\hline F5 & 150 & 5.1 & $0.37 \pm 0.01 \mathrm{abcd}$ & $56.38 \pm 0.51^{c}$ & $0.37 \pm 0.02 \mathrm{c}$ & $9.65 \pm 0.21 \mathrm{e}$ \\
\hline
\end{tabular}

$\mathrm{F} 1=\mathrm{CS}(0.5 \% \mathrm{w} / \mathrm{v})$ and $\mathrm{MD}(9.5 \% \mathrm{w} / \mathrm{v})$ in an aqueous solution of glacial acetic acid $(1.0 \% \mathrm{v} / \mathrm{v})$;

$\mathrm{F} 2=$ Only $\mathrm{MD}(10 \% \mathrm{w} / \mathrm{v})$ in coconut shell liquid smoke;

$\mathrm{F} 5=\mathrm{CS}(1.5 \% \mathrm{w} / \mathrm{v}): \mathrm{MD}(8.5 \% \mathrm{w} / \mathrm{v})$ in coconut shell liquid smoke;

$\left.{ }^{*}\right)=$ data collected from cyclon and vessel fraction;

Reported means ( \pm standard deviations) obtained from 3 replications measured triplo;

Data within column followed by different superscripts are significantly different at $P<0.05$ by Tukey Methods range test 


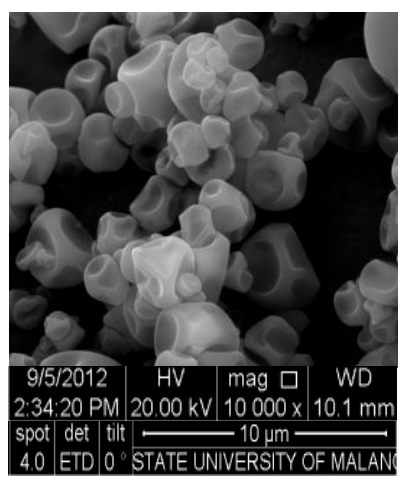

a
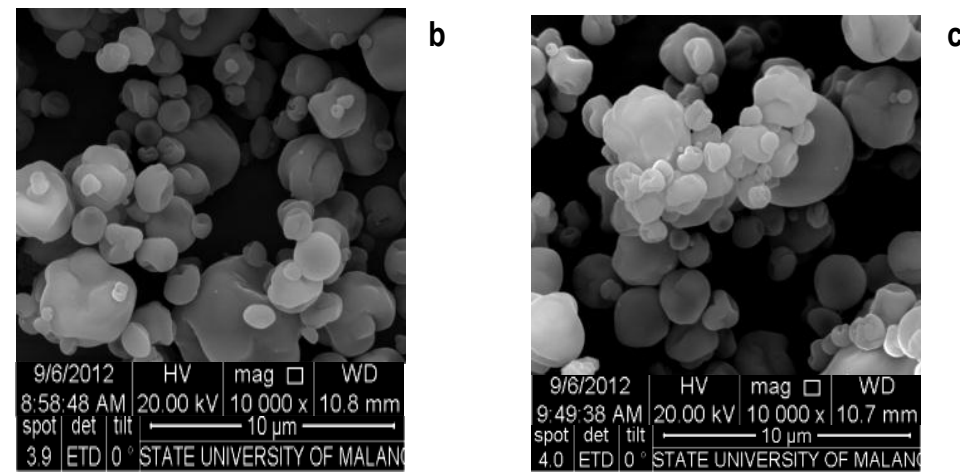

Figure 2. SME $(10,000 \mathrm{X})$ of spray-dried powders (a) chitosan $(0.5 \% \mathrm{w} / \mathrm{v})+$ maltodextrin $(9.5 \% \mathrm{w} / \mathrm{v})$ in acetic acid, (b) only maltodextrin $(10 \% \mathrm{w} / \mathrm{v})$ in liquid smoke, and (c) chitosan (1.5\% w/v) + maltodextrin $(8.5 \% \mathrm{w} / \mathrm{v})$ in liquid smoke
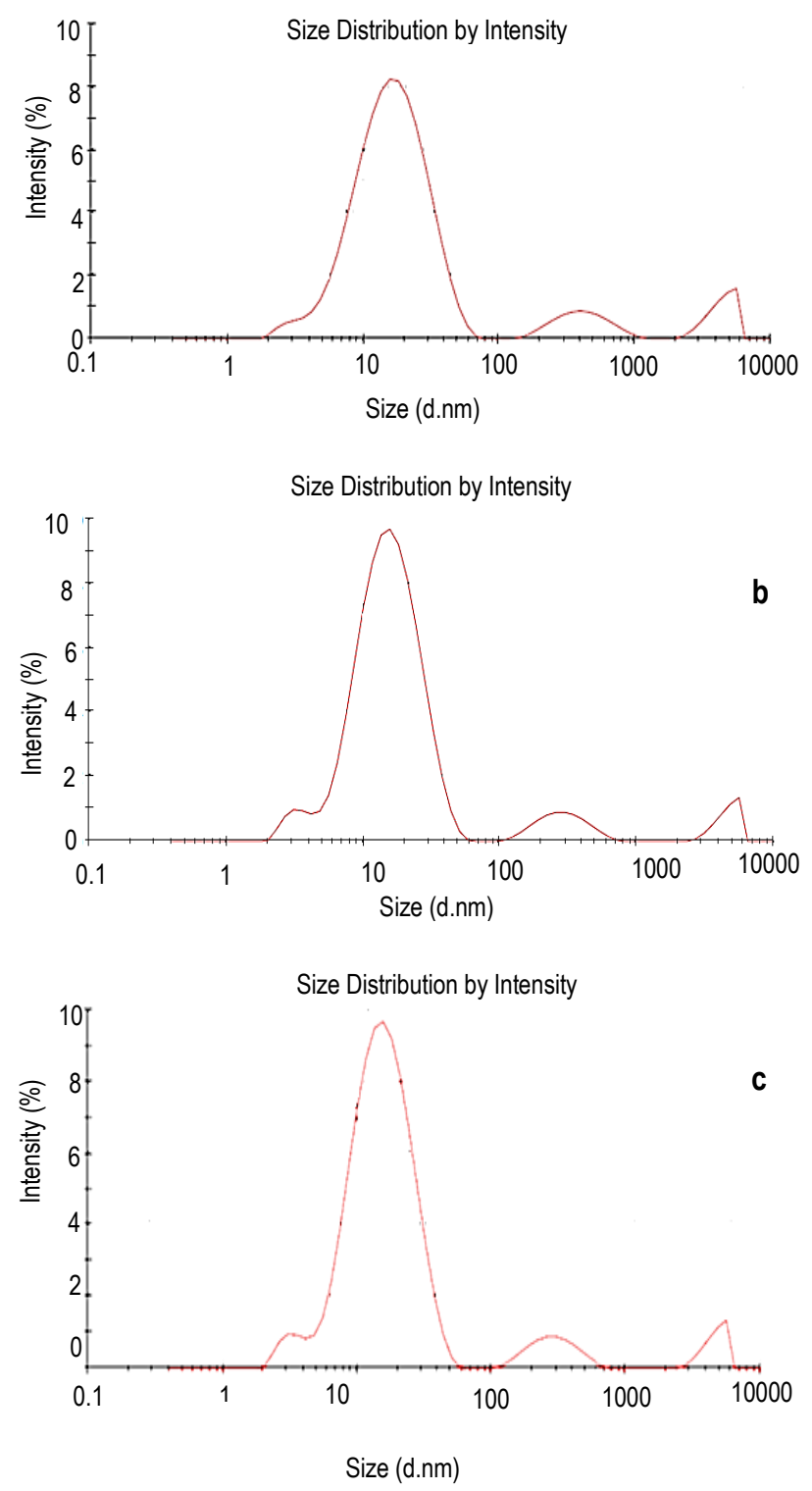

Figure 3. Particle size distribution powders generated from (a) chitosan $(0.5 \% \mathrm{w} / \mathrm{v})+$ maltodextrin $(9.5 \% \mathrm{w} / \mathrm{v})$ in acetic acid, (b) only maltodextrin $(10 \% \mathrm{w} / \mathrm{v})$ in liquid smoke, and (c) chitosan $(1.5 \% \mathrm{w} / \mathrm{v})+$ maltodextrin $(8.5 \% \mathrm{w} / \mathrm{v})$ in liquid smoke

\section{Particle size distribution}

The mean particle size distribution of powders loaded as CS and $\mathrm{MD}$ nanoparticles are shown in Figure 3. The average size of particles formed from CS $(0.5 \% \mathrm{w} / \mathrm{v})+\mathrm{MD}(9.5 \% \mathrm{w} / \mathrm{v})$ in acetic acid was $16.21 \mathrm{~nm}$, only MD (10\% w/v) in coconut shell liquid smoke $14.87 \mathrm{~nm}$, and CS $(1.5 \% \mathrm{w} / \mathrm{v})+\mathrm{MD}(8.5 \% \mathrm{w} / \mathrm{v})$ in coconut shell liquid smoke $13.43 \mathrm{~nm}$. The differences in zeta potential with change in $\mathrm{pH}$ showed; at higher $\mathrm{pH}$ more crosslinked particles are formed compared to the lower pH (data not shown). Zhang et al., (2004) publish a commercial low molecule wheight CS to prepare CS nanoparticle at a concentration level of $0.1 \%(\mathrm{w} / \mathrm{w})$ in a mixture of CS and TPP (weight ratio of $5: 1$ ) resulting in a bimodal particle size distribution ranging between 153 and $500 \mathrm{~nm}$. The results were supported with the findings of $\mathrm{Hu}$ et al., (2008), and they found the interactions between phenolic groups of liquid smoke and amino groups of CS (over phosphate group of TPP) may lead to decrease in the crosslinking density.

\section{CONCLUSION}

The increase in inlet air temperature up to $150^{\circ} \mathrm{C}$ during spray drying improved the yield. The highest particle yield of $73.02 \%$ was achieved at $150^{\circ} \mathrm{C}$ and also found to be dependant on the feed rate at $5.1 \mathrm{~mL} /$ minute. The moisture content of the powder was found to be dependent on the inlet air temperature of the drying air. Morphologically, SEM revealed the larger particles were dimpled, whereas smaller particles were more spherical. The smallest mean particle size of $13.43 \mathrm{~nm}$ was obtained from CS $1.5 \% \mathrm{w} / \mathrm{v}+\mathrm{MD} 8.5 \% \mathrm{w} / \mathrm{v}$ in liquid smoke with the spray drying operation conditions inlet air temperature $150^{\circ} \mathrm{C}$, feed flow rate $5.1 \mathrm{~mL} /$ minute, aspirator rate $50 \%$, atomization air rotameter $30 \mathrm{~mm}$ and the nozzle cleaner set to 4. This study demonstrates that spray drying can successfully produce dried coconut shell liquid smoke powder from suspensions of nanomaterials. Therefore, it might be also be a good candidate for applying in food processing. 


\section{ACKNOWLEDGEMENTS}

We gratefully acknowledge Ministry of Research and Technology of Republic of Indonesia for "Insentif Riset Sinas" research funding in contract number 1.61/SEK/IRS///2012. The first author would like to thank the Ministry of Education and Culture of Republic of Indonesia for PhD fellowship.

\section{REFERENCES}

Anal AK, Stevens WF, Remuan-L'opez C. 2006. Ionotropic cross-linked chitosan microspheres for controlled release of ampicillin. Int $\mathrm{J}$ Pharm 312: 166-73. DOl: 10.1016/i.ijpharm.2006.01.043.

Anal AK. 2010. Microencapsulation and its application in delivery of bioactives compounds in foods system. Innov Sci: 34-40.

Bansode SS, Banarjee SK, Gaikwad DD, Jadhav SL, Thorat RM. 2010. Microencapsulation : A Review. Pharm Sci Rev Res 1: 38-43.

Chin S, Nazimah SAH, Quek S, Man YBC. 2010. Effect of thermal processing and storage condition on the flavour stability of spray-dried durian powder. LWT Food Sci Technol 43: 856-861 DOI: 10.1016/j.Iwt.2010.01.001.

Darmadji P, Izumimoto M. 1994. Effect of chitosan in meat preservation. Meat Sci 38: 243-254. DOI: 10.1016/03091740(94)90114-7.

Darmadji P, Izumimoto M. 2009. Biopreservative Prototype Making of Liquid Smoke, Safety Evaluation and Industrial Profile as an Alternative Preservation to Replace Formaldehyde. Report $2^{\text {nd }}$ years Insentive Applied. The Ministry of Research and Technology of Republic of Indonesia.

Dib TCMA, Menezes HC, Santos, AB, Grosso CRF. 2003. Study of the microcapsulation of camu-camu (Myrciaria dubia) juice. J Microencapsul 20: 443-448. DOl: 10.1080/0265204021000060291.

Drusch S, Schwarz K. 2006. Microencapsulation properties of two different types of $n$-octenylsuccinate-derivatised starch. Eur Food Res Technol 222: 155-164. DOI: 10.1007/s00217-005-0020-3.

Drusch S, Serfert Y, Scampicchio M, Schmidt-Hansberg B, Schwarz K. 2007. Impact of physicochemical characteristics on the oxidative stability of fish oil microencapsulated by spray-drying. J Agric Food Chem 55:11044-11051. DOl: 10.1021/jf072536a.

Fang X, Shima M, Adachi S. 2005. Effects of drying conditions on the oxidation of lineoleic acid encapsulated with gum arabic by spray-drying. Food Sci Technol Res 11: 380-384 DOI: 10.3136/fstr.11.380.

Fuchs M, Turchiuli C, Bohin M, Cuvelier ME, Ordonnaud C Peyrat-Maillard MN, Dumoulin E. 2006. Encapsulation of oil in powder using spray drying and fluidised bed agglomeration. $\mathrm{J}$ Food Eng 75: 27-35. DOl: 10.1016/i.joodeng.2005.03.047.

Grenha A, Gomes ME, Rodrigues M, Santo VE, Mano JF, Neves NM, Reis RL. 2010. Development of new chitosan/ carrageenan nanoparticles for drug delivery applycations. J Biom Materials Res 92: 1265-1272. DOl: 10.1021/jf801111c.

Hong JH, Choi, YH. 2007. Physico-chemical properties of protein-bound polysaccharide from Agaricus blazei Murill prepared by ultrafiltration and spray drying process. Int $\mathrm{J}$ Food Sci Tech 42: 1-8. DOI: 10.1111/j.13652621.2005.01116.X.

Hu B, Pan C, Sun Y, Hou Z, Ye H, Zeng X. 2008. Optimization of fabrication parameters to produce chitosantripolyphosphate nanoparticles for delivery of tea catechins. J Agric Food Chem 56: 7451-7458. DOI: 10.1021/ff801111c.

Lindeløv JS, Wahlberg M. 2009. Spray drying for processing of nanomaterials. J Phys Conf Ser 170: 012-027. DOl: 10.1088/1742-6596/170/1/012027.

Loksuwan J. 2007. Characteristics of microencapsulated bcarotene formed by spray drying with modified tapioca starch, native tapioca starch and maltodextrin. Food Hydrocoll 21: 928-935. DOI: 10.1016/j.foodhyd.2006.10.011.

Newton DE. 2007. Food Chemistry. Facts On File, Inc. New York.

Oliveira WP, Souza CRF, Kurozawa LE, Park KL. 2010. Spray Drying of Food and Herbal Products. In Woo MW, Mujumdar AS, Daud WRW. (Eds). Spray Drying Techn. P. 113-156. Published in Singapore,

Patel RP, Patel MP, Suthar AM. 2009. Spray drying technology: an overview. Indian J Sci Tech 2: 44- 47.

Pranoto Y, Rakshit SK, Salokhe VM. 2005. Enhancing antimicrobial activity of chitosan films by incorporating garlic oil, potassium sorbate and nisin. LWT Food Sci Technol 38: 859-865. DOI: 10.1016/j.Iwt.2004.09.014.

Reineccius GA. 1988. Spray-drying of food flavors. In Risch SJ, Reineccius GS. (Eds.), Flavor Encapsulation. ACS Symposium Series, 370. P.55-66. Washington, DC: American Chemical Society. DOI: 10.1021/bk-1988$0370 . \operatorname{ch} 007$

Reineccius GA. 2004. The spray drying of food flavors. Drying Techn 22: 1289-1324. DOI: 10.1081/DRT-120038731.

Righetto AM, Netto FM. 2005. Effect of encapsulation materials on water sorption, glass transition, and stability of juice from immature acerole. Int J Food Prop 8: 337-346. DOI: 10.1081/JFP-200060262.

Sebastien G. 2004. Microencapsulation: industrial appraisal of existing technologies and trends. Trends Food Sci Technol 15: 330-347. DOI: 10.1016/i.tifs.2003.10.005.

Tewa-Tagne P, Briancon S, Fessi H. 2007. Preparation of redispersible dry nanocapsules by means of spray-drying: Development and characterisation. Eur $\mathrm{J}$ Pharm Sci 30: 124-135. DOI: 10.1016/..ejps.2006.10.006.

Vila A, S'anchez A, Tob'ıo M, Calvo P, Alonso MJ. 2002. Design of biodegradable particles for protein delivery. $J$ Control Release 78: 15-24. DOI: 10.1016/S01683659(01)00486-2.

Zhang H, Oh M, Allen C, Kumacheva E. 2004. Monodisperse chitosan nanoparticles for mucosal drug delivery. Biomacromolecules 5: 2461-2468. DOI: 10.1021/bm0496211. 
Versi Online:

http://journal.ipb.ac.id/index.php/jtip

DOI: 10.6066/jtip.2012.23.2.173

Hasil Penelitian

J. Teknol. dan Industri Pangan, Vol. XXIII No. 2 Th. 2012

Zuraida I, Sukarno, Budijanto S. 2011. Antibacterial activity of fish ball preservation. Int Food Res J 18: 405-410. coconut shell liquid smoke (CS-LS) and its application on 